\title{
PERENCANAAN PEMBIAYAAN BERBASIS \\ PLANNING PROGRAMMING BUDGETTING SYSTEM (PPBS) DI SEKOLAH DASAR ISLAM TERPADU ANNI'MAH BANDUNG
}

\author{
Acep Nurlaeli \\ Universitas Singaperbangsa Karawang \\ Email: acep.nurlaeli@fai.unsika.ac.id
}

\begin{abstract}
ABSTRAK
Perencanaan pembiayan pendidikan yang baik berkontribusi terhadap mutu pengelolaan pendidikan. Perencanaan pembiayaan pendidikan merupakan total biaya yang dikeluarkan baik oleh individu peserta didik, keluarga yang menyekolahkan anak, warga masyarakat perorangan, kelompok masyarakat, maupun yang dikeluarkan oleh pemerintah untuk kelancaran pendidikan. Satuan pendidikan dituntut mampu menyusun perencanaan pembiayaan secara tepat. Permasalahan utama penelitian ini yaitu bahwa satuan pendidikan memerlukan adanya model perencanaan pembiayaan yang dipandang efektif. Penelitian ini bertujuan untuk menggambarkan perencanaan pembiayaan pendidikan Berbasis PPBS (Planning, Programming, Budgeting System). Penelitian menggunakan metode deskriptif kualitatif. Hasil penelitian menemukan bahwa Model PPBS (planning, programming, budgeting system) merupakan model perencanaan, penyusunan program dan penganggaran yang dipandang sebagai suatu sistem yang tak terpisahkan satu sama lainnya. Penelitian ini menyimpulkan bahwa perencanaan pembiayaan berbasis PPBS merupakan proses komprehensif dalam pengambilan keputusan karena model PPBS merupakan suatu pendekatan sistematik yang berusaha untuk menetapkan tujuan, mengembangkan program, menentukan besaran biaya, dan proses penganggaran yang merefleksikan kegiatan program jangka panjang. Perencanaan berbasis PPBS berkontribusi positif pada peningkatan mutu Sekolah Dasar (SD) Islam terpadu (IT) Anni'mah yang teridentifikasi ditandai adanya peningkatan mutu guru, meningkatnya mutu siswa, lingkungan belajar semakin kondusif, disiplin sekolah semakin baik, ketersediaan sumber belajar memadai, partisipasi orang tua meningkat, serta satuan biaya semakin terukur dengan jelas.
\end{abstract}

Kata kunci: Perencanaan, Program, Budgeting Sistem

\section{ABSTRACT}

A good educational financial planning contributes to the educational management quality. Educational financing planning is the total costs incurred both by students, families who send their children to school, citizens, community groups, 
and those incurred by the government so the education can run well. The education unit is required to be able to arrange financing plans appropriately. The ultimate problem of this research is the education unit requires an effective financial planning model. This research aims to describe the educational financing planning based on PPBS (Planning, Programming, Budgeting System). This research uses qualitative descriptive methods. The results found that the PPBS Model (planning, programming, budgeting system) is a model of planning, programming, and budgeting which are seen as an inseparable system from one another. This research concludes that PPBS-based financing planning is a comprehensive process in decision-making because the PPBS model is a systematic approach that seeks to set goals, develop programs, determine the amount of costs, and budgeting processes that reflect long-term program activities. PPBS-based planning contributes positively to improve the quality of integrated Islamic Elementary School (IT) Anni'mah that is marked by an increasing in teachers' quality, improved students' quality, a more conducive learning environment, better school discipline, availability of adequate learning resources, the increasing of parents' participation, and the unit costs are increasingly measurable.

Key Words: Planning, Programming, Budgeting System

\section{PENDAHULUAN}

Permasalahan keuangan menyebabkan banyak sekolah tidak dapat melakukan kegiatan belajar mengajar secara optimal, tidak mampu menggaji guru, serta sulit mengadakan sarana dan prasarana pembelajaran. Tuntutan reformasi menghendaki pendidikan yang murah dan berkualitas, tetapi pendidikan berkualitas senantiasa memerlukan dana yang cukup banyak (Masditou, 2017).

Pembiayaan pendidikan merupakan instrumen penting dalam pencapaian tujuan. Program pendidikan yang bagus memerlukan konsep perencanaan pembiayaan yang matang. Tanpa perencanaan yang baik, program sekolah sulit untuk dapat direalisasikan. Kalaupun terealisasi maka hanya menimbulkan keborosan biaya. Munculnya SPM akan membantu dalam merinci anggaran pendidikan yang dibutuhkan untuk setiap detailnya. Meskipun pada kenyataannya daerah belum siap dengan hal ini dikarenakan kurangnya sumber daya manusia yang mengerti akan perhitungan perencanaan pembiayaan dan pemenuhan SPM yang belum terpenuhi sehingga perencanaan pendidikan tidak dilakukan dengan baik.

Perencanaan pembiayan pendidikan haruslah dilakukan dengan baik, pemerintah harus dapat menganggarkan pada pemenuhan kualitas pendidikan dan pembangunan pendidikan bukan hanya terfokus pada gaji guru, infrastruktur juga harus diperhatikan. Tetapi sayangnya pemerintah kita melakukan perencanaan anggarannya dulu tanpa menetapkan target program sehingga yang terjadi adalah anggaran ada dan program tidak jelas yang menghasilkan anggaran yang tersedia digunakan untuk program apapun yang terkadang tidak jelas (Achmad dkk., 2016). 
Sedangkan tujuan Standar Nasional Pendidikan (SNP) selanjutnya disebutkan dalam pasal 4, SNP bertujuan menjamin mutu pendidikan nasional dalam rangka mencerdaskan kehidupan bangsa dan membentuk watak serta peradaban bangsa yang bermartabat. Dari 8 standar mutu pendidikan yang harus dipenuhi oleh madrasah, maka keberadaan standar pembiayaan menjadi salah satu penentu ketercapaian pemenuhan 7 standar mutu yang lain. Hal ini terjadi karena tanpa biaya maka pendidikan tidak berjalan, terlepas dari siapa yang akan mengeluarkan biaya untuk kepentingan pendidikan (pemerintah atau masyarakat). Demikian juga jika biaya yang tersedia banyak tetapi tidak dikelola dengan baik, maka akan terjadi inefisiensi sistem pendidikan (Suadi, 2019).

Biaya dapat diartikan sebagai sejumlah uang yang dihasilkan dan dibelanjakan untuk berbagai keperluan. Sedangkan biaya pendidikan dapat diartikan sejumlah uang yang dihasilkan dan dibelanjakan untuk berbagai keperluan penyelenggaraan pendidikan. Pembiayaan pendidikan adalah total biaya yang dikeluarkan baik oleh individu peserta didik, keluarga yang menyekolahkan anak, warga masyarakat perorangan, kelompok masyarakat maupun yang dikeluarkan oleh pemerintah untuk kelancaran pendidikan (Suhardan dkk., 2012). Pembiayaan pendidikan adalah semua pengeluaran yang memiliki kaitan dengan penyelenggaraan pendidikan (Harsono, 2007). Pembiayaan pendidikan dapat digolongkan menjadi empat jenis yaitu pembiayaan pendidikan yang dikeluarkan oleh pemerintah, pembiayaan pendidikan yang dikeluarkan oleh masyarakat orang tua/wali siswa, pembiayaan pendidikan yang dikeluarkan oleh masyarakat bukan orang tua/wali siswa, pembiayaan pendidikan dari lembaga pendidikan itu sendiri (Sonedi dkk., 2017).

Terdapat pendekatan dalam penyusunan anggaran yaitu: 1) Pendekatan tradisional (line-item/object of expenditure budget). Pendekatan ini menampilkan anggaran dalam prespektif sifat dasar (nature) dari sebuah pengeluaran atau belanja. Pendekatan tradisional ini tidak memiliki tolok ukur; 2) Pendekatan kinerja, yaitu memiliki proses untuk mengklasifikasikan anggaran berdasarkan kegiatan dan unit organisasi tanpa meninggalkan rincian belanja. Anggaran yang telah terkelompokkan dalam kegiatan-kegiatan akan memudahkan bagi pihak yang berkepentingan melakukan pengukuran kinerja dengan indikator yang telah dibuatnya terlebih dahulu; 3) Pendekatan anggaran berbasis nol (Zero Based Budgeting-ZBB). Pendekatan tersebut menghendaki setiap aktivitas atau program yang telah dilakukan pada tahun sebelumnya tidak secara otomatis dapat dilanjutkan. Setiap aktivitas harus dievaluasi setiap tahun untuk menentukan apakah aktivitas itu akan diadakan tahun ini dengan melihat konstribusi yang diberikan kepada tujuan organisasi; 4) Pendekatan sistem perencanaan dan penganggaran terpadu (Planning Programming and Budgeting System-PPBS). Pendekatan tersebut memandang bahwa penyusunan anggaran bukanlah proses terpisah dan berdiri sendiri, melainkan sebuah bagian yang tidak terpisah dari proses perencanaan dan perumusan program kegiatan (Nordiawan dkk., 2007).

Model PPBS (Planning, Programming, Budgeting, System), dalam bahasa Indonesia adalah sistem perencanaan, penyusunan, program dan penganggaran (SP4). Model ini bermakna bahwa perencanaan, penyusunan program dan penganggaran dipandang sebagai suatu system yang tidak terpisahkan satu sama lainnya. 
Berdasarkan uraian pendekatan di atas, pada dasarnya manajemen memiliki proses cara mencapai tujuan sehingga setiap kegiatan harus direncanakan, ditentukan waktunya, serta berapa besar dana yang dibutuhkan untuk melaksanakannya. Pendekatan dan model perencanaan dan penganggaran terpadu (baik aktivitas yang dilakukan secara global ataupun pada unit terkecil) dapat dibuat tahapan PPBS sebagai berikut:

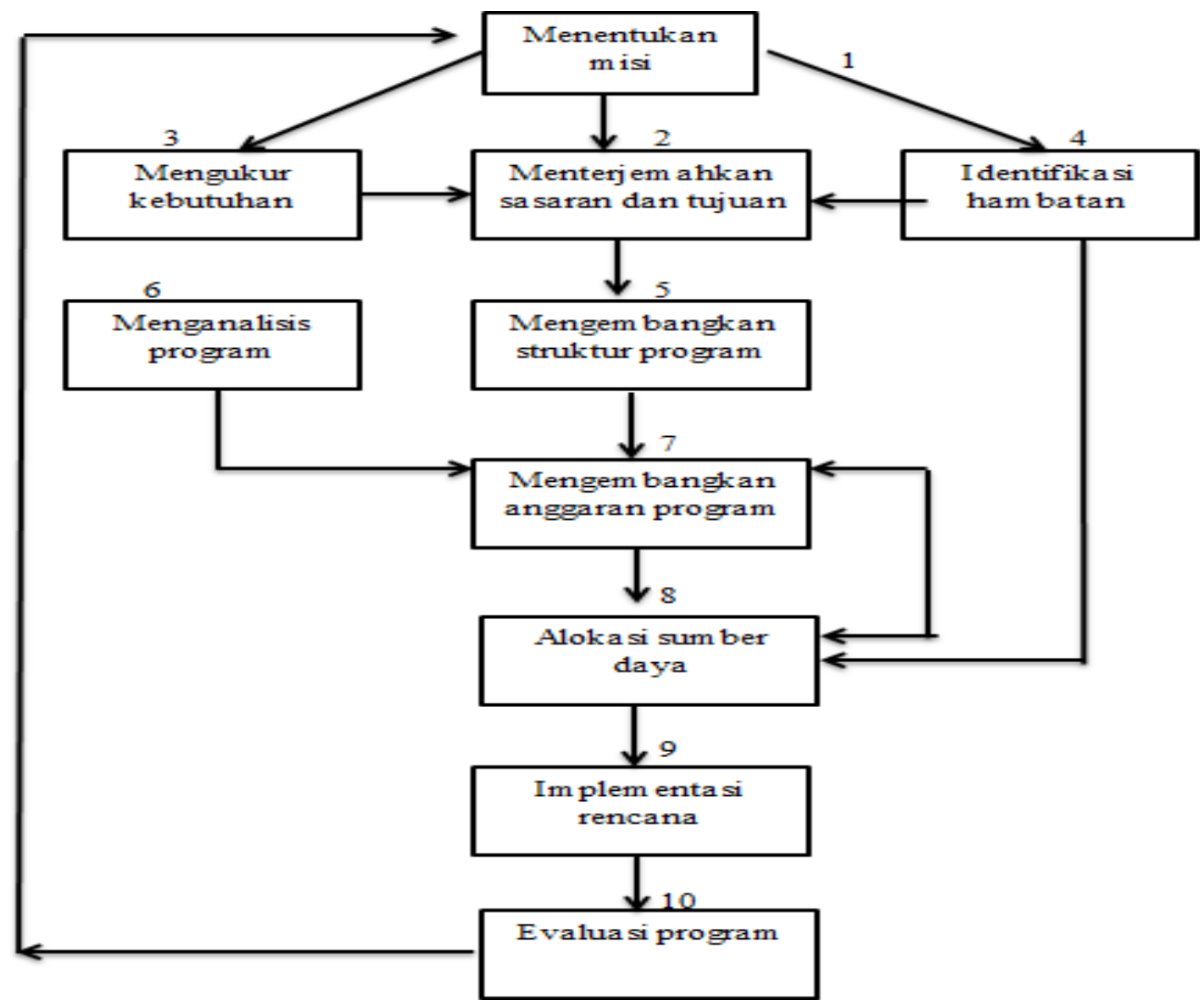

Sumber: (Nordiawan dkk., 2007)

Gambar 1. Tahapan PPBS (Planning, Programming, Budgeting System)

Tahapan PPBS (Planning, Programming, Budgeting System) jika dilakukan penganalisaan akan memiliki manfaat dalam manajemen pembiayaan yaitu meningkatnya efektifitas dan efisiensi penggunaan dana, meningkatkan akuntabilitas dan transparansi, serta dapat meminimalisasi penyalahgunaan dana. Jika di dalam praktik pengelolaan dana atau memanajemen pembiayaan yang dilakukan minimal sesuai dengan format sesuai dengan tahapan PPBS (Planning, Programming, Budgeting System).

Adapun langkah yang dapat dilakukan dalam perencanaan pembiayaan adalah menganalisis kebutuhan, merencanakan pembiayaan, dan mengatur struktur finansial. Menganalisa kebutuhan dapat dilakukan melalui identifikasi masalah atau kebutuhan yang terjadi pada jangka waktu pendek ataupun jangka waktu panjang. Berdasarkan kebutuhan tersebut diperhitungkan anggaran dana yang akan dibelanjakan, sehingga muncul perencanaan cara memperoleh dana dan waktu belanja atau penggunaan dana. Perencanaan memperoleh dan 
membelanjakan dana disebut sebagai pengaturan struktur finansial. Langkah ini dapat dirinci sebagai berikut: 1) Membedakan kebutuhan dan keinginan. Produk yang dibeli belum tentu merupakan kebutuhan tetapi hanya sekedar keinginan. Dalam format tahapan PPBS (Planning, Programming, Budgeting System) yang diperbolehkan masuk dalam kelompok perencanaan adalah kegiatan atau produk yang benar-benar dibutuhkan. Sehingga pos pendanaan akan sesuai dengan pos yang sebenarnya. 2) Mengelompokkan pengeluaran. Pengeluaran yang akan didanai harus dikelompokkan pada jangka waktu pendek atau jangka waktu panjang. 3) Membatasi pengeluaran, ditentukan terlebih dahulu dalam bentuk besaran anggaran setiap kegiatan, dengan demikian akan sesuai pada pos yang sebenarnya. 4) Mencatat pengeluaran yang sudah dilakukan. 5) Menabung. Dalam hal ini jika anggaran lebih besar dari pada realisasinya, maka sisa anggaran ini dapat dikategorikan dalam tabungan. Namun seyogyanya untuk menabung harus diambilkan terlebih dahulu dari sebagian dana yang dimiliki sebelum dianggarkan pada kegiatan atau sebelum perencanaan dibuat. 6) Menghindari hutang, caranya adalah harus bijak dalam menggunakan uang. 7) Mengurangi kegiatan yang tidak bermanfaat, misalnya nongkrong ataupun ngrumpi. Kecuali kegiatan ini diisi dengan kegiatan berwirausaha, sekalian nongkrong atau ngrumpi. 8) Berwirausaha, dilakukan untuk mencari tambahan dana. 9) Berpuasa yang dalam manajemen pembiayaan ini mohon tidak diniatkan untuk mengurangi pengeluaran, tetapi berpuasa semata-mata untuk mencari ridho dan pahala dari Alloh Swt (Syamsuddin, 2004).

Setiap sekolah memerlukan model perencanaan pembiayaan pendidikan. Penelitian ini menggunakan model PPBS (Planning, Programming, Budgeting System). Perencanaan, penyusunan, program, dan penganggaran dipandang sebagai suatu sistem yang tak terpisahkan satu sama lainnya yang dapat meningkatkan mutu sekolah. Terdapat sejumlah permasalahan perencanaan pembiayaan, di antaranya: 1) ketidakjelasan pencairan dana BOS yang tidak jelas tiap tahunnya; 2) sarana dan prasarana yang belum lengkap; 3) adanya orang tua siswa yang telat bayar SPP; 4) adanya guru yang mengajar tidak sesuai dengan latar belakang pendidikannya.

Permasalahan utama penelitian ini yaitu: bagaimanakah model perencanaan pembiayaan berbasis PPBS (Planning, Programming, Budgeting System) untuk meningkatkan mutu di SD IT Anni'mah Margahayu Bandung. Penelitian ini bertujuan untuk mendeskripsikan perencanaan pembiayaan pendidikan berbasis PPBS (Planning, Programming, Budgeting System). Menjelaskan kelebihan dan kekurangan perencanaan pembiayaan pendidikan berbasis PPBS (Planning, Programming, Budgeting System). Menjelaskan kontribusi perencanaan pembiayaan pendidikan berbasis PPBS (Planning, Programming, Budgeting System) terhadap mutu SD IT Anni'mah Margahayu Bandung. Kegunaan penelitian merupakan bentuk harapan hasil yang akan dicapai akan mempunyai kegunaan. Penelitian ini diharapkan berkontribusi sebagai sarana pengembangan dan penerapan disiplin ilmu program studi Manajemen Pendidikann Islam, sebagai wahana untuk mengaplikasikan teori yang diperoleh selama belajar di bangku kuliah, serta menambah pengetahuan tentang lembaga pendidikan Islam terutama untuk mengetahui model perencanaan pembiayaan berbasis PPBS (Planning, Programming, Budgeting System), sebagai bahan rujukan atau bahan pertimbangan bagi peneliti lain 
dalam melakukan penelitian yang sama atau sejenis atau yang berkaitan dengan perencanan pembiayaan berbasis PPBS (Planning, Programming, Budgeting System). Hasil penelitian ini diharapkan dapat menjadi pertimbangan dalam meningkatkan kegiatan pendidikan secara produktif di SD IT Anni'mah Margahayu Bandung melalui model perencanaan pembiayaan berbasis PPBS (Planning, Programming, Budgeting System).

\section{METODE}

Penelitian ini bersifat deskriptif, yaitu untuk memperoleh deskripsi data mengenai bagaimana model perencanaan pembiayaan berbasis PPBS (Planning, Programming, Budgeting System) untuk meningkatkan mutu di SD IT Anni'mah Margahayu Bandung. Penelitian deskriptif merupakan suatu penelitian yang diupayakan untuk mengamati permasalahan secara sistematis dan akurat mengenai fakta dan sifat objek tertentu. Penelitian deskriptif ditujukan untuk memaparkan dan menggambarkan fakta-fakta berdasarkan cara pandang atau kerangka berpikir tertentu (Pupuh, 2011, hlm. 98).

Subjek pada penelitian ini adalah Kepala Sekolah SD IT Anni'mah Margahayu Bandung dan bagian Tata Usaha dan objek yang diambil hanya bagian pengelola kesiswaan saja serta melakukan pengamatan terhadap perencanaan pembiayaan model PPBS (Planning, Programming, Budgeting System). Penelitian ini dilakukan selama 1 minggu mulai dari tanggal 20-24 Desember 2019. Penulis memilih hari Jum'at sampai Selasa untuk melakukan wawancara terhadap kepala sekolah dan pengelola pembiayaan sekaligus melakukan observasi pengamatan kepada subjek yang diteliti. Alasan memilih hari tersebut karena ketersediaan kepala sekolah meluangkan waktu untuk melakukan wawancara, karena pasca diadakannya Ujian Akhir Semester pada sekolah tersebut. Namun dalam pelaksanaan observasi (pengamatan secara langsung) dilakukan mulai dari sebelum hari Jum'at.

Pada penelitian ini, peneliti menggunakan observasi sistematis, karena disini peneliti meneliti model perencanaan pembiayaan berbasis PPBS (Planning, Programming, Budgeting System) untuk meningkatkan mutu di SD IT Anni'mah Margahayu Bandung. Setelah proses pengumpulan data selesai, langkah yang akan dilakukan selanjutnya ada mengolah data yang telah didapatkan. Pengolahan data ini merupakan aspekyang penting di dalam metode ilmiah, karena dalam hal ini metode tersebut dapat memberikan makna yang berguna dalam memecahkan masalah penelitian. Tahap-tahap yang dilakukan dalam pengolahan data hasil penelitian yaitu melakukan organisasi data agar tersusun secara rapi dan sistematis, melakukan analisis awal untuk dapat mensistematisasi data secara lengkap dan mendetail sehingga dapat memunculkan gambaran tentang topik yang diteliti, menganalisis data dengan kepekaan teoritis yang mengacu pada kemampuan untuk memperoleh pemahaman, memberi makna pada data, dan memilah mana yang penting dan mana yang tidak serta pemahaman konseptual tentang data.

\section{HASIL DAN PEMBAHASAN}

\section{Profil SD IT Anni'mah Margahayu Bandung}

Sekolah Dasar Islam Terpadu Anni'mah berada di bawah naungan Yayasan Anni'mah. Yayasan Anni'mah yang beralamat di JI. Sampora 
Sukamenak, Kecamatan Margahayu Kabupaten Bandung didirikan di Bandung pada tahun 1997 berdasarkan Akta Notaris No. 03 Tanggal 16 September 1996 dengan Notaris Hj. Inne Sudarsih, S.H. Yayasan Anni'mah bergerak di bidang Pendidikan dengan visi dan misi yang jelas untuk berperan aktif memajukan Dunia Pendidikan.

SD IT Anni'mah Margahayu bandung berdiri sejak tahun 1997 dan telah meluluskan sebanyak 16 angkatan, yaitu angkatan Tahun Pelajaran 2002/2003 s.d. Tahun Pelajaran 2017/2018 dengan kualitas lulusan yang membanggakan. Dalam perjalanannya hingga Tahun Pelajaran 2018/2019 ini, alhamdulillah SD IT Anni'mah Margahayu Bandung telah memiliki reputasi yang sangat baik, hal ini ditandai dengan animo masyarakat untuk mendaftarkan putra/putrinya ke SD IT Anni'mah Margahayu Bandung dari tahun ke tahun mengalami peningkatan. SD IT Anni'mah Margahayu Bandung memiliki siswa/siswi sebanyak 708 orang dengan jumlah guru dan karyawan sebanyak 57 orang.

SD IT Anni'mah Margahayu Bandung merupakan salah satu SD Plus di Kabupaten Bandung yang memiliki ciri khas dalam metode dan muatan pelajaran, khususnya muatan lokal, dalam hal ini Pendidikan Keagamaan dan Pendidikan Ekstrakurikuler. Selain itu, sekolah selalu melakukan inovasi dalam berbagai hal untuk menunjang lancarnya proses pembelajaran, termasuk dalam bidang sarana dan prasarana.

\section{Perencanaan Pembiayaan Pendidikan Berbasis PPBS (Planning, Programming, Budgeting System) di SD IT Anni'mah Margahayu Bandung}

Tahapan penyusunan perencanaan pembiayaan berbasis PPBS (Planning, Programming, Budgeting System) di SD IT Anni'mah Margahayu Bandung banyak ditekankan pada penyusunan rencana sejumlah program yang akan dilaksanakan. Rencana disusun dalam rangka mendukung pencapaian tujuan institusional SD IT Anni'mah Margahayu Bandung dan dalam upaya mencapai tujuan pendidikan nasional. Pengukuran manfaat penggunaan dana, dilihat dari sudut pengaruhnya terhadap lingkungan secara keseluruhan, baik dalam jangka pendek maupun dalam jangka panjang. Pengelompokan pos-pos anggaran didasarkan atas tujuan-tujuan yang hendak dicapai di masa yang akan datang.

Proses penyusunan rencna pembiayaan menggunakan model PPBS (Planning, Programming, Budgeting System) di SD IT Anni'mah Margahayu Bandung menempuh beberapa tahap yaitu menentukan tujuan yang hendak dicapai, mengkaji pengalaman-pengalaman di masa lalu, melihat prospek perkembangan yang akan datang, menyusun rencana yang bersifat umum mengenai apa yang akan dilaksanakan.

Setelah keempat tahap di atas selesai disusun, tahap selanjutnya SD IT Anni'mah Margahayu Bandung menyusun program pelaksanaan rencana yang telah ditetapkan. Berdasarkan program pelaksanaan ditentukan berapa jumlah dana yang diperlukan untuk melaksanakan program-program tersebut.

Langkah-langkah implementasi PPBS (Planning, Programming, Budgeting System) pada SD IT Anni'mah Margahayu Bandung meliputi: 1) menentukan tujuan umum organisasi dan tujuan unit organisasi dengan jelas, 2) mengidentifikasi program-program dan kegiatan untuk mencapai tujuan yang telah ditetapkan, 3) mengevaluasi berbagai alternatif program dengan 
menghitung pos benefit dari masing-masing program, 4) pemilihan program yang memiliki manfaat besar dengan biaya yang kecil, 5) alokasi sumber daya kemasing-masing program yang disetujui, 6) program yang disusun harus terkait dengan tujuan organisasi dan tersebar ke seluruh bagian organisasi.

Terdapat sejumlah aspek yang perlu diperhatikan dalam menyusun perencanaan pembiayaan berbasis PPBS (Planning, Programming, Budgeting System), yaitu untuk menerapkan sistem ini, dituntut kemampuan dalam menyusun rencana dan program secara terpadu. Kemudian dibutuhkan informasi yang lengkap, baik informasi masa lalu maupun informasi masa yang akan datang yang relevan dengan kebutuhan penyusunan rencana dan program tersebut. Serta pengawasan mulai dilaksanakan sebelum pelaksanaan sampai selesainya pelaksanaan rencana dan program.

\section{Kelebihan dan Kekurangan Model Perencanaan Pembiayaan Berbasis PPBS (Planning, Programming, Budgeting System)}

Setiap model perencanaan pembiayaan memiliki kelebihan dan kekurangan. Kelebihan model pembiayaan berbasis PPBS (Planning, Programming, Budgeting System) adalah pertama, memudahkan dalam pendelegasian tanggung jawab dari manajemen puncak ke manajemen menengah. Kedua, dalam jangka panjang dapat mengurangi beban kerja. Ketiga, memperbaiki kualitas pelayanan melalui pendekatan sadar biaya (costconsciousness/cost awareness) dalam perencanaan program. Keempat, lintas departemen sehingga dapat meningkatkan komunikasi, koordinasi, dan kerja sama antar departemen. Kelima, menghilangkan program yang overlapping atau bertentangan dengan pencapaian tujuan organisasi. Keenam, PPBS (Planning, Programming, Budgeting System) menggunakan teori marginal utility, sehingga mendorong alokasi sumber daya secara optimal.

Perencanaan pendidikan sangat dekat kaitannya dengan struktur penduduknya. Ada empat pendekatan dalam perencanaan pendidikan. Salah satunya pendekatan perencanaan pendidikan yang menitikberatkan pemanfaatan biaya secermat mungkin untuk mendapatkan hasil pendidikan yang seoptimal mungkin, baik secara kuantitatif maupun kualitatif. Pendidikan ini hanya diadakan jika memberikan keuntungan yang relatif pasti, baik bagi penyelenggara maupun peserta didik. Sebagai contoh, pembukaan sekolahsekolah Magister Manajemen, Magister Bisnis Administrasi, dan kursus-kursus. Kelemahan pendekatan ini adalah pengelolaan dana pendidikan terutama di negara berkembang masih sangat lemah (Aisyah, 2018).

PPBS (Planning, Programming, Budgeting System) bermakna bahwa perencanaan, penyusunan program dan penganggaran dipandang sebagai suatu sistem yang tak terpisahkan satu sama lainnya. PPBS (Planning, Programming, Budgeting System) merupakan suatu proses yang komprehensif untuk pengambilan keputusan yang lebih efektif. Beberapa ahli memberikan pengertian, antara lain: Kast Rosenzweig mengemukakan bahwa PPBS (Planning, Programming, Budgeting System) merupakan suatu pendekatan yang sistematik yang berusaha untuk menetapkan tujuan, mengembangkan programprogram, untuk dicapai, menemukan besarnya biaya dan alternatif dan menggunakan proses penganggaran yang merefleksikan kegiatan program jangka panjang. Sedangkan Harry J. Hartley mengemukakan bahwa PPBS 
(Planning, Programming, Budgeting System) merupakan proses perencanaan yang komprehensif yang meliputi program budget sebagai komponen utamanya.

Model PPBS (Planning, Programming, Budgeting System) menunjukkan bahwa perencanaan, penyusunan program dan penganggaran dipandang sebagai suatu sistem yang tak terpisahkan satu sama lainnya. PPBS (Planning, Programming, Budgeting System) merupakan suatu proses yang komprehensif untuk pengambilan keputusan yang lebih efektif. Model PPBS (Planning, Programming, Budgeting System) dipahami sebagai pendekatan yang sistematik yang berusaha untuk menetapkan tujuan, mengembangkan program-program, menentukan besarnya biaya, dan proses penganggaran yang merefleksikan kegiatan program jangka panjang.

Sifat-sifat esensial PPBS (Planning, Programming, Budgeting System) yakni: (1) memerinci secara cermat dan menganalisis secara sistematik terhadap tujuan yang hendak dicapai; (2) mencari alternatif-alternatif yang relevan, serta cara yang berbeda-beda untuk mencapai tujuan; (3) menggambarkan biaya total dari setiap alternatif, baik langsung atau pun tidak langsung, biaya yang telah lewat atau pun biaya yang akan datang, baik biaya yang berupa uang maupun biaya yang tidak berupa uang; (4) memberikan gambaran tentang efektifitas setiap alternatif dan bagaimana alternatif itu mencapai tujuan; dan (5) membandingkan dan menganalisis alternatif tersebut, yaitu mencari kombinasi yang memberikan efektivitas yang paling besar dari sumber yang ada dalam pencapaian tujuan (Priyanto, 2011).

Karakteristik PPBS (Planning, Programming, Budgeting System) yaitu pertama, berfokus pada tujuan dan aktivitas (program) untuk mencapai tujuan. Kedua, secara eksplisit menjelaskan implikasi terhadap tahun anggaran yang akan datang karena PPBS (Planning, Programming, Budgeting System) berorientasi pada masa depan. Ketiga, mempertimbangkan semua biaya yang terjadi. Keempat, dilakukan analisis secara sistematik atas berbagai alternatif program, yang meliputi identifikasi tujuan, identifikasi secara sistematik alternatif program untuk mencapai tujuan, estimasi biaya total dari masing-masing alternatif program, dan estimasi manfaat (hasil) yang ingin diperoleh dari masingmasing alternatif program.

Pendekatan sistem perencanaan dan penganggaran terpadu PPBS (Planning, Programming, Budgeting System) memandang bahwa penyusunan anggaran bukanlah proses terpisah dan berdiri sendiri, melainkan sebuah bagian yang tidak terpisah dari proses perencanaan dan perumusan program kegiatan. Berdasarkan model dan pendekatan PPBS (Planning, Programming, Budgeting System) pada dasarnya di dalam manajemen telah terproses tentang apa yang akan menjadi tujuan sehingga setiap kegiatan harus direncanakan, ditentukan waktunya, hingga berapa besar dana yang dibutuhkan untuk melaksanakannya. Dengan pendekatan dan model perencanaan dan penganggaran terpadu (baik aktivitas yang dilakukan secara global ataupun pada unit terkecil) (Astuty, 2016).

Perencanaan pembiayaan berbasis PPBS (Planning, Programming, Budgeting System) merupakan salah satu wujud aktivitas manajemen. Manajemen adalah suatu proses yang terdiri dari perencanaan, pengorganisasian, pelaksanaan dan pengawasan yang dilakukan untuk menentukan dan mencapai tujuan dengan menggunakan sumber manusia dan sumber lain (Terry, 2013). Manajemen itu adalah suatu proses perencanaan, 
pengorganisasian, kepemimpinan, pengendalian dan pengarahan serta pengawasan dalam mengorganisasi anggota dan mempergunakan seluruh sumber daya organisasi lainnya untuk mencapai tujuan ecara efektif dan efisien. Manajemen dapat juga dipahami sebagai proses kegiatan tertentu yang saling berkaitan untuk mencapai tujuan-tujuan yang telah ditentukan.

Adapun kekurangan dari model PPBS (Planning, Programming, Budgeting System) adalah sebagai berikut: Pertama, PPBS membutuhkan sistem informasi yang canggih, ketersediaan data, adanya sistem pengukuran, dan staf yang memiliki kapabilitas tinggi. Kedua, implementasi PPBS membutuhkan biaya yang besar karena PPBS membutuhkan teknologi yang canggih. Ketiga, PPBS bagus secara teori, namun sulit untuk diimplementasikan. Keempat, PPBS mengabaikan realitas politik dan realitas organisasi sebagai kumpulan manusia yang kompleks. Kelima, PPBS merupakan teknik anggaran yang statistically oriented. Penggunaan statistik terkadang kurang tajam untuk mengukur efektivitas program. Statististik hanya tepat untuk mengukur beberapa program tertentu saja. Keenam, pengaplikasian PPBS menghadapi masalah teknis. Hal ini terkait dengan sifat progam atau kegiatan yang lintas departemen sehingga menyulitkan dalam melakukan alokasi biaya. Sementara itu sistem akuntansi dibuat berdasarkan departemen bukan program.

\section{Kontribusi Perencanaan Pembiayaan berbasis PPBS (Planning, Programming, Budgeting System) pada Mutu Sekolah SD IT Anni'mah Margahayu Bandung}

Hasil penelitian memperoleh data bahwa mutu sekolah SD IT Anni'mah Margahayu Bandung teridentifikasi pada kategori sangat baik. Hal ini ditandai dengan adanya kondisi mutu guru yang sangat baik. Mutu guru pada SD IT Annim'ah Margahayu Bandung memang terlihat dari $90 \%$ guru lulusan S1, 10\% guru lulusan S2 dan lainnya.

Strategi pembelajaran sudah menggunakan strategi yang inovatif, serta penggunaan teknologi yang masih terbatas oleh keterbatasan sarana. Evaluasi proses pembelajaran sudah diperhatikan. Sedangkan untuk indikator lainnya, yaitu mutu siswa, lingkungan belajar, disiplin sekolah, kesediaan sumber belajar, partisipasi orang tua, satuan biaya termasuk sangat baik. Mutu siswa meningkat dari waktu ke waktu ditandai dengan perolehan keunggulan akademik dan non akademik seperti ekstrakulikuler. Selain itu, umumnya peserta didik dinyatakan lulus dalam menyelesaikan program pembelajaran, mutu hasil ujian meningkat, angka putus sekolah rendah, dan angka lulusan siswa sangat tinggi. Hal tersebut didukung oleh partisipasi masyarakat dalam pembiayaan SD IT Anni'mah Margahayu Bandung yang sangat baik dan didukung bantuan dana dari pemerintah.

Berdasarkan hasil penelitian terdapat hubungan yang kuat antara perencanaan pembiayaan pendidikan berbasis PPBS (Planning, Programming, Budgeting System) dengan mutu sekolah. Secara individual, hubungan manajemen pembiayaan pendidikan berbasis PPBS (Planning, Programming, Budgeting System) terhadap mutu sekolah menunjukkan bahwa manajemen pembiayaan pendidikan berkontribusi signifikan terhadap mutu sekolah. Manajemen pembiayaan pendidikan berbasis PPBS (Planning, Programming, Budgeting System) secara langsung mempengaruhi mutu SD IT Anni'mah 
Margahayu Bandung sebesar $50 \%$, terdapat $50 \%$ sisanya merupakan pengaruh dari faktor lainnya. Dalam hal tersebut, pada tahap pelaksanaan pembiayaan sudah mencapai kategori sangat baik, setiap kegiatan manajemen pembiayaan dilaksanakan sesuai dengan pelaksanaan yang disusun sebelumnya. Hal tersebut disesuaikan dengan peraturan yang berlaku dan mengikat anatara pembuatan RKAS dengan anggaran dana BOS yang dialokasikan pemerintah. Keterlambatan dana BOS bisa diatasi dengan meminjam dana ke yayasan.

Manajemen pembiayaan sekolah mengalokasikan sumber dana yang didapatnya dengan efisien kepada komponen yang mengarah pada standar sarana dan prasarana dan kebutuhan sekolah lainnya. Selain itu, terdapat beberapa komponen yang dapat mempengaruhi manajemen pembiayaan, diantaranya adalah biaya pelaksanaan pembelajaran dan ekstrakulikuler, pengadaan perpusatakaan, pengadaan bahan habis pakai, perawatan sekolah, serta jasa dan daya yang digunakan sekolah, maka pengaruh secara langsung dan tidak langsung dari manajemen pembiayaan pendidikan terhadap mutu sekolah menunjukan total sebesar $75 \%$.

\section{SIMPULAN}

Pembiayaan pendidikan adalah total biaya yang dikeluarkan baik oleh individu peserta didik, keluarga yang menyekolahkan anak, warga masyarakat perorangan, kelompok masyarakat maupun yang dikeluarkan oleh pemerintah untuk kelancaran pendidikan. Model PPBS (Planning, Programming, Budgeting System) merupakan model perencanaan, penyusunan program dan penganggaran yang dipandang sebagai suatu sistem yang tak terpisahkan satu sama lainnya. PPBS (Planning, Programming, Budgeting System) merupakan suatu proses yang komprehensif untuk pengambilan keputusan yang lebih efektif karena model PPBS (Planning, Programming, Budgeting System) merupakan suatu pendekatan sistematik yang berusaha untuk menetapkan tujuan, mengembangkan program-program, menentukan besarnya biaya, dan proses penganggaran yang merefleksikan kegiatan program jangka panjang. Mutu sekolah SD IT Anni'mah teridentifikasi pada kategori sangat tinggi. Berdasarkan hasil tersebut, mutu guru menjadi dimensi dengan skor kecenderungan rata-rata tinggi. Adapun beberapa sekolah, kompetensi guru terkadang kurang diperhatikan. Sedangkan untuk indikator lainnya, yaitu mutu siswa, lingkungan belajar, disiplin sekolah, kesediaan sumber belajar, partisipasi orang tua, satuan biaya, sudah berada pada kategori sangat tinggi. Pengaruh yang diberikan oleh manajemen pembiayaan pendidikan terhadap mutu pendidikan SD IT Anni'mah Margahayu Bandung berada pada kategori kuat. Rata-rata kecenderungan SD di Kabupaten Bandung sudah pada kategori yang sangat baik pada tahap pelaksanaan pembiayaan.

\section{REFERENSI}

Achmad, D., Gumilang, G., \& Herlina. (2016). Perencanaan Pembiayaan Pendidikan (Studi Kasus di Sekolah Dasar). PEDAGOGIA Jurnal IImu Pendidikan, 12(2), 40. https://doi.org/10.17509/pedagogia.v12i2.3326 Aisyah, A. (2018). Perancanaan Dalam Pendidikan. Adaara: Jurnal Manajemen Pendidikan Islam, 6(1), 715-731. https://doi.org/10.35673/ajmpi.v7i1.314 
Astuty, H. S. (2016). Manajemen Pembelanjaan Dalam Perspektif Mahasiswa Pendidikan Ekonomi. Jurnal Teladan:Jurnal IImu Pendidikan dan Pembelajaran, 1(1), 47-58.

Harsono. (2007). Pengelolaan Pembiayaan Pendidikan. Pustaka Publisher. Masditou. (2017). Manajemen Pembiayaan Pendidikan Menuju Pendidikan yang Bermutu. ANSIRU PAI: Jurnal Pengembangan Profesi Guru Pendidikan Agama Islam, 1(2). http://jurnal.uinsu.ac.id/index.php/ansiru/article/view/1518

Nordiawan, D., Putra, I. S., \& Rahmawati, M. (2007). Akuntansi Pemerintahan. Salemba Empat.

Priyanto, D. (2011). Pengembangan Perencanaan Pendidikan Islam (Konsep Strategi Pengembangan di Indonesia). INSANIA: Jurnal Pemikiran Alternatif Kependidikan, 16(3). https://doi.org/10.24090/insania.v16i3.1594

Pupuh, F. (2011). Metode Penelitian Pendidikan. Pustaka Setia.

Sonedi, S., Jamalie, Z., \& Majeri, M. (2017). Manajemen Pembiayaan Pendidikan Bersumber dari Masyarakat (Studi Pada MTs Darul Ulum Palangka Raya). FENOMENA, 9(1), 25. https://doi.org/10.21093/fj.v9i1.702

Suadi. (2019). Model Pembiayaan Pendidikan Berbasis Masyarakat. ALTA'DIB: Jurnal Kajian IImu Kependidikan, 8(2). http://ejournal.unhasy.ac.id/index.php/al-tadib/article/view/375

Suhardan, D., Ridwan, \& Enas. (2012). Ekonomi dan Pembiayaan Pendidikan. Alfabeta.

Syamsuddin, L. (2004). Manajemen keuangan Perusahaan (Konsep Aplikasi dalam: Perencanaan, Pengawasan, dan Pengambilan Keputusan). PT Raja Grafindo Persada.

Terry, G. R. (2013). Prinsip-Prinsip Manajemen. Bumi Aksara. 